\title{
Ronsard and the ghost of Astyanax
}

\section{Alice Roullière}

Trinity Hall College, University of Cambridge

ar723@cam.ac.uk alice.aurelia@gmail.com

07960678816

Wychfield Site, Storey's Way, CB30DZ, Cambridge

Alice Roullière is a second-year PhD student in French at Trinity Hall College, Cambridge. She is currently writing her thesis on the representation of ghosts in Ronsard's poetic works under the supervision of Dr Timothy Chesters. 


\section{Ronsard and the ghost of Astyanax}

This article examines the emergence and transformation of Francion's epic character in Ronsard's works from 1550 to 1578 , as an example of failed necromantic imitation. This study of Fancion's genesis in Ronsard's works relies on the close reading of the variations of 'Ode de la Paix' and the beginning of the Franciade, as well as on the analysis of the myth's reception before and after 1572 . In the 1550 'Ode de la Paix au roy', the memory of the Virgilian intertext directly undermines the epic hero's identity since he is presented as Hector's only son, who in the classical tradition is named Astyanax and dies in Troy. Drawing on the problematic memory of Astyanax, I argue that Ronsard's awareness of Francion's ghostly aura explains the numerous corrections in 'Ode de la Paix' and the ghostly decoy introduced in the Franciade to justify the prince's survival. Francion's fragile identity illustrates the complex application of the Renaissance concept of imitation and the difficulty to create a national myth for France.

Keywords: Ronsard, Francion, Astyanax, ghost, epic, nation

\section{Introduction}

The aim of this paper is to explore the development of the language of ghosts in early modern texts about Ronsard's epic character Francion. Francion, also called Francus, is the eponymous hero of the Ronsardian epic the Franciade (1572) elaborated between 1550 and 1578 first for Henri II, and then Charles IX. Although the project was acclaimed and celebrated in anticipation by most of the poetic community, Ronsard never finished the epic and in 1578 he officially brought his incomplete epic to a close by giving the death of Charles IX as the main reason for the impossibility to carry on with this project. Although Ronsard never wrote the sequel after the first four books he published in 1572, the unfinished state of the Franciade did not hinder its popularity. ${ }^{1}$ Yet Ronsard's poetic

${ }^{1}$ On the one hand, the word 'failure' has been dismissed from critical work and replaced by a focus on the 'mélancolie' and the 'manque' at work in Ronsard's epic poetics (see Caroline Trotot, 'La place des images dans la poétique ronsardienne de 
choices are a topic of discussion before and after the publication of the epic and in particular the problematic identity of Francion who is explicitly or implicitly associated with the ghost of Astyanax. The most obvious example of this ghost metaphor is featured in the dedicatory letter to James I of England written by Jean de Schélandre that prefaces his epic for the house of Stuarts, La Stuartide (1611):

Belle certes, Sire, non l'invention mais la matiere, \& digne esteuf de tomber en la main d'un bon ioüeur, propre à relever ce divin chantre de Loire de la peine qu'il a prize à ressusciter un Astyanax \& à fonder la majesté de cent Roys sur la vanité d'un fantosme. ${ }^{2}$

Schélandre is an admirer of Ronsard ('ce divin chantre de Loire') but he wants to create a distinction between the 'verité' of the Stuartide's argument and Ronsard's epic based

l'histoire.', in Histoire et fiction, ed. Gisèle Séginger and Piotr Śniedziewski, Littérature et histoire--Colloques Poznań--Paris, v. 1 (Poznań: Éditions de la Société des amis des sciences et des lettres de Poznań, 2009), 9-24. Caroline Trotot, 'Ronsard et les fantômes de Troie', Fabula Colloques, 05/01/2017, http://www.fabula.org/colloques/document3809.php.). On the other hand, a few critics worked to prove the actual popularity of the Ronsardian epic in the $16^{\text {th }}$ century, from Jean-Claude Ternaux who defined the Franciade as a 'réussite partielle' (Jean-Claude Ternaux, 'La Franciade de Ronsard: Échec Ou Réussite?', La Revue Des Amis de Ronsard, no. 13 (2000): 117-35.) to Philip John Usher who has shown the immediate influence of Ronsard's epic on Pierre Lescot, Jean Goujon and Toussaint Dubreuil (Phillip John Usher, Epic Arts in Renaissance France, First edition (Oxford: Oxford University Press, 2014), 'Ronsard's Franciade: From National Genealogy to Tragic Love Story', p. 120-58.) and François Rouget who studied the many reeditions of the epic (François Rouget, Ronsard et Le Livre: Etude de Critique Génétique et D’histoire Littéraire, Cahiers D'humanisme et Renaissance, v. 95, 109 (Genève: Droz, 2010).

${ }^{2}$ Jean de Schélandre, Les deux premiers livres de la Stuartide en l'honneur de la tresillustre maison des Stuarts, (Paris: Fleury Bourriquant, 1611), p. 4. 
on a 'fantosme' and a resurrected Astyanax. ${ }^{3}$ Regardless of the actual popularity of the epic, early modern readers like Schélandre express not only admiration but also puzzlement when it comes to the identity of the character of Fancion, no other than Astyanax himself, son of Hector and Andromache, who, contrary to the Homeric tradition, does not die in Troy: the young heir is miraculously saved from the wrath of the Greeks by the divine intervention of Jupiter who substitutes a decoy made of clouds for the real prince. This survival is the starting point of an epic journey in which AstyanaxFrancion is meant to become the founder of a new realm across the Danube, the precursor of the kingdom of France. The rescue of Astyanax-Francion is the theme of one of the Franciade's liminary text, a poem in Latin by the hand of Jean Dorat:

Juppiter e Phrygia servavit turre cadentem

Ficto dissimulans Astyanaca dolo:

Scilicet ut Francos mutato nomine Reges

Conderet, unde suos Francia jactat avos

A Jove servatae periisset tempore rursus

Astyanacteae gloria tota domus

Ni Jovis exemplum tu nunc, Ronsarde, secutus

Fictis servasses Astyanacta modis.

As Astyanax fell from a tower in Troy, Jupiter saved him with a decoy in order to hide him. His aim of course was to establish under a new name the dynasty of Frankish kings, from which France boasted descent. All the glory of the house of Astyanax might have perished yet again, although it had been saved by Jupiter, had you, Ronsard not followed Jupiter's example and saved Astyanax with a poetic counterfeit. ${ }^{4}$

In this liminary poem, Ronsard's poetic invention is compared to a divine intervention, capable of changing a dreadful event at the moment when it is happening, altering its

\footnotetext{
${ }^{3}$ Bruno Méniel, Renaissance de L'épopée: La Poésie Épique En France de 1572 À 1623, Travaux D’humanisme et Renaissance, no. 389 (Genève: Droz, 2004).

${ }^{4}$ Pierre de Ronsard, The Franciad, translation Philip John Usher, (New York: AMS Press, Inc., 2010), p. 17.
} 
meaning and its course. It is particularly striking that Dorat chooses to turn Jupiter's carefully designed plan to save Astyanax in the Franciade into a last-minute substitution, as the body of the prince falls from the tower. Relying on other myths of substitution and metamorphosis in extremis, ${ }^{5}$ Dorat heightens the sense of danger and emergency that remains latent in the verb 'servare' (to save, to preserve from danger), stressing the extremity of Ronsard's poetic venture and praising in contrast the all-powerful success of his creative invention.

Dorat is one of the many early modern writers to grant a meta-poetic and political dimension to the crafting of the argument of the Ronsardian epic. The fiction of the decoy that saves Francion can be understood as a conceptual metaphor that informs the reader on the status of fiction in the epic. Yet, the superposition of the hero Francion and the deceased Astyanax is not only read as a triumphant fiction but also as a 'fantosme' (Schélandre), in the context of an explicit disbelief into an epic hero described as dead or ghostly.

This introduction of the language of ghosts and haunting into literary criticism is a new feature of $16^{\text {th }}$ century writing which novelty is difficult to understand for a modern and postmodern reader familiar with topics such as the haunting of the past and spectral figures since what has been identified as a 'spectral turn' following the publication of Spectres de Marx by Derrida in $1993 .{ }^{6}$ Although the vocabulary and the concepts

\footnotetext{
${ }^{5}$ See the many metamorphosis accounted for in Ovid in his Metamorphosis and the myth of Iphigenia, replaced in some versions by a doe by the intervention of Artemis.

${ }^{6}$ Derrida's association of deconstruction with the presence-absence of the spectre, both arrivant and revenant, figure the disjointment of time has proven to be a productive framework to understand postmodern art and literature, to the point that recent works have worried that the spectre might have been stretched a bit too thin, used
} 
inherited by the spectral turn are now used in Renaissance studies on ghosts and apparitions, it is also necessary to emphasize the limits of spectralities studies for early modern texts written within a Christian epistemological model. In Walking by Night, Timothy Chesters pays specific attention to the context of appearance and nuances of words such as 'fantôme' or 'spectre' and shows how in the late $16^{\text {th }}$ century ghosts are first associated with theological debates between Catholics and Huguenots but also become hybrid characters in ghost stories repository of secular worries and desires. ${ }^{7}$ In a more recent study on death and tenses in French Renaissance literature, Neil Kenny emphasizes the importance of the Christian representation and conceptualization of death as in direct contradiction with postmodern deconstruction. ${ }^{8}$

If we find ghosts as apparitions, fiction characters and allegories in texts of the late $16^{\text {th }}$ century, the word 'ghost' or the rhetorics of haunting are not commonly used as metaphors to talk about poetry, poetics or the art of writing itself in the first half of the $16^{\text {th }}$ century. The possible meta-poeticity of ghost and ghost tales appears in Montaigne's essay 'Des Boiteux' analysed by Chesters in which the heated process of writing Les Essais echoes the excitement produced by ghost stories. ${ }^{9}$ Before Montaigne, the poets of

as an empty umbrella word to refer without discrimination to the past, death and vision.

${ }^{7}$ Chesters for example shows that the word 'spectre' is an invention of the late $16^{\text {th }}$ century, chosen by Le Loyer for its neutrality and to avoid associations with religious debates on apparitions while the word 'revenant' is an $19^{\text {th }}$ century coinage. Timothy Chesters, Ghost Stories in Late Renaissance France: Walking by Night, Oxford Modern Languages and Literature Monographs (Oxford ; New York: Oxford University Press, 2011).

${ }^{8}$ Neil Kenny, Death and Tenses: Posthumous Presence in Early Modern France, First edition (Oxford, UK; New York, NY: Oxford University Press, 2015).

${ }^{9}$ Chesters, Ghost Stories in Late Renaissance France, p. 252. 
La Pléiade, in particular Du Bellay and Ronsard explicitly use metaphors of life and death in their arts poétiques, but never mentioned ghosts. Indeed for Ronsard, the poetic eulogy and the imitation of the classics did not create haunted texts but had the power of 'arracher vifs les hommes hors du tumbeau'. ${ }^{10}$ This expression is emblematic of La Pléiade's poetics and has been the object of an abundant scholarship. ${ }^{11}$ Although the image of the dead rising from their grave might have a ghostly ring for a modern reader, and pagan undertones for the early modern Huguenot, it is in fact framed in terms of Christian resurrection. The reference to necromancy rituals inspired by classical literature serves a celebration of the renewed life of the resurrected past, in a process closer to reincarnation than haunting and expressed through Christian commonplaces related to salvation and resurrection.

In studies about French Renaissance poetics, the resistance of the past has been studied first in the 90s by authors such as Thomas Greene or Terence Cave, and in a more recent articles, by Pascale Chiron and Caroline Trotot. Greene and Cave questioned the magical process of literary resurrections by highlighting the cracks and limits of the imitation process. Greene for example analyses the Renaissance imitative process in terms of failed or successful necromancy and/or resurrection (what he calls the 'revivalist

${ }^{10}$ In 'Epitaphe de François de Bourbon conte d'Anguian' (Livre II, Ode XX), Ronsard celebrates ancient poets, his models in poetical necromancy because they can give a 'second vivre' (v.9) to men: 'Durant leurs jours avoient une coutume/D'arracher vifs les hommes du tumbeau.', Pierre de Ronsard, Euvres, ed. Laumonier, t. 2, ... Similar expressions can be found throughout the four books of Odes and the Bocage for example : Odes IV, II: 'T'arracher vivant toi meme/Hors de l'oublieus tumbeau' (v.23-24), Bocage IV: 'Les eust arraché du tumbeau/Faisant leur nom vivre, \& revivre' (v. 176-177). 
initiative'). ${ }^{12}$ Out of the four imitative strategies he identifies (sacramental, eclectic, heuristic and dialectical), Greene considers that only heuristic and dialectical imitation hold the potential to achieve a genuine literary resurrection. Both heuristic and dialectical strategies advertise 'their derivation from the subtexts they carry with them', but also create distance: by doing so, they provoke a heuristic reading which can 'force us to recognize the poetic distance traversed' ${ }^{13}$ The dialectical strategy of imitation accounts for texts which not only distance themselves from their 'putative genesis' but also assert their own superiority from the subtext. For Greene, therefore, the successful rewriting which occurs in imitation - and which allows a 'vital passage'- needs to simultaneously refer to a subtext which is constitutive of the new text, and to keep it at a distance by modernizing it. ${ }^{14}$ Greene seems to think that the actualisation of the 'revivalist initiative' that is the driving force of many Renaissance texts, is more likely to fail than to succeed, in falling into the trap of the sacramental or eclectic approach. ${ }^{15}$

12 Thomas M. Greene, The Light in Troy: Imitation and Discovery in Renaissance Poetry, Elizabethan Club Series 7 (New Haven: Yale University Press, 1982), Chapter 'Imitation and anachronism', p. 28-53.

${ }^{13}$ Greene, The Light in Troy, p. 40.

14 'Out of the indefinite number of texts stretching behind it in endless regression, the humanist poem singles out one text as its putative genesis and defines itself through its rewriting, its “modernizing”, its aggiornamento of that text', Greene, The Light in Troy, p. 41.

15 'It can fail if the original imitative gesture is made in bad faith, if the subtext is ornamental rather than constitutive, or if the subtext is misread so ineptly as to kill the possibility of a vital passage. It can fail if either subtext or surface text overwhelms the other by a disproportionate contrast of substance and value. The text can lapse into a misplaced scrupulosity of sacramental piety or into a fruitless game of eclectic manipulation; or it can simply fail to produce an interesting model of history: it can fail to be heuristic. For each category of misfires examples could 
Although the language related to failure could be read as inexact in the context of the Franciade, Greene's emphasis on the subtext has the advantage of illuminating the expressions of doubt, disbelief and discontent that in early modern texts focused on the argument of the Franciade and the genesis of Francion as a character. Readers of the Franciade were convinced by the 'genesis' of the epic and they did not resist the myth of Trojan origins but they focused on something about Francion that did somehow not achieve a 'vital passage', critical in the case of the epic which was supposed to materialise a translatio studii that reflected the translatio imperii. ${ }^{16}$

Chiron and Trotot, partly inspired by the spectral turn approach, have recently published articles focusing on ghost figures in Ronsard's works. Chiron sees Du Bellay's ghost in the 'Elegie à Louis des Masures' as emblematic of the presence-absence of Du Bellay's poetry in Ronsard's works. ${ }^{17}$ Trotot understands ghost figures as the culmination of Ronsard's poetics of images: ghosts and the 'motif fantômal' that pervades the Franciade are at the crossroads of the resurrection or translatio of classical authors and the melancholy of history, created by the violence of contemporary events. She writes about the book III of the epic:

be found, but they do not in themselves invalidate their artistic genesis.' Greene, The Light in Troy, p. 47.

${ }^{16}$ Corinne Noirot-Maguire explains that translatio can describe 'linguistico-poetic transfer' and 'geo-political transfer' in Corinne Noirot-Maguire, 'At the Helm, Second in Command: Du Bellay and La Mort de Palinure', Phillip John Usher and Isabelle Fernbach, eds., Virgilian Identities in the French Renaissance, Gallica, v. 27 (Woodbridge, Suffolk, UK ; Rochester, NY: D.S. Brewer, 2012), p. 190 .

${ }^{17}$ Pascale Chiron, 'Ronsard-Du Bellay, Histoire D'une Hantise', in Fantômes D'écrivains, ed. Anne Chamayou and Nathalie Solomon, Études (Perpignan: Presses universitaires de Perpignan, 2013), 55-71. 
Le Livre III amplifie ce motif fantômal en confrontant en particulier le héros à la mort d'un compagnon qui apparaît comme son double. Il le désigne comme « un second moymesme » (III, v. 766). Or on insiste sur l'importance qu'il y a à lui donner des funérailles pour qu'il ne hante pas les vivants. L'épopée qui s'annonçait comme résurrection du passé devient funérailles de son propre héros dédoublé. ${ }^{18}$

Taking my cue from Trotot's analysis of the 'motif fantômal' present in the Franciade, I argue in this article that Francion was a 'héros dédoublé' from its very creation because of the character of Astyanax, and that the language of ghosts contemporary of the Franciade's publication mainly focused on the problematic relationship of the epic hero with its Homeric alter-ego. By going back to the first apparition of the epic hero, and following the thread of its reception, and the corrections made to the Ronsardian version of the Trojan origins of the French, I examine the relevance of the ghost metaphor in the hectic creation of a French mythical identity. In doing so, I provide a dynamic reading of the elaboration of the myth of Francion as a competition with the figure of the deceased Astyanax. Through a succession of close readings, I attempt to rethink the elaboration of a potential ghostly-ness in the case of the Franciade, while seeking to understand the extent to which the disruptions introduced by Francion influenced the creation and the reception of the epic.

\section{'Astyanax redivivus'19}

The very first verses of the Franciade (1572) explicitly state the identification of Francion with Astyanax-Scamandre:

Muse qui tiens les sommets de Parnasse, Guide ma langue, \& me chante la race Des Roys Francoys yssus de Francion Enfant d'Hector, Troyen de nation Qu'on appelloit en sa jeunesse tendre

18 Trotot, 'La place des images dans la poétique ronsardienne de l'histoire.'

${ }^{19}$ I borrow this expression from: Alain Niderst, 'Ronsard, Andromaque et Attila', Travaux de Littérature, 4 (1991), p. 117-26. 
Astyanax, \& du nom de Scamandre : ${ }^{20}$

Denis Bjaï considers that the first book of the Franciade can be read as an explanatory development of this original and surprising piece of news: Francion is Astyanax which implies that Astyanax survived the ransacking of Troy. Bjaï argues that the identity of Francion is complex but not problematic, as the puzzling double identity of Francion is immediately resolved by an intricate yet well-structured argument whose root is the decoy of clouds. ${ }^{21}$ To understand the scope of Ronsard's strategy, it is necessary to give a brief overview of the sources used as material to shape the French epic hero. The character of Francion belongs to a composite medieval tradition which asserts that, similarly to Rome, the French have Trojan ancestors. The works of Colette Beaune ${ }^{22}$ and Robert E. Asher ${ }^{23}$ are instrumental in laying out the various stages and transformations of this origin myth in France. Both studies retrace how a supposed ancestor of the Franks who first is featured in the Chronicles of Fredegarius $\left(7^{\text {th }}\right.$ century), progressively becomes linked to the Trojan royal family. The story that seems to prevail, although Francion remains a very debated character in Europe during the Renaissance, is the one presented by Jean Lemaire de Belges in the Illustrations de Gaule et Singularitez de Troie (1510). Lemaire de Belges explains that Francion is in fact Laodamas: Hector's second son and the brother of Astyanax. ${ }^{24}$ As for the question of the survival of Astyanax, some ancient texts present a

${ }^{20}$ Pierre de Ronsard, Euvres Complètes, XVI (1) (Franciade,1572), ed. Paul Laumonier, (Paris: Librairie Marcel Dider, 1950), p. 29, v. 1-6.

${ }^{21}$ Bjaï, La Franciade Sur Le Métier, p. 99-101.

${ }^{22}$ Colette Beaune, Naissance de La Nation France, (Paris: Gallimard, 1993), p.19-29.

${ }^{23}$ R. E. Asher, National Myths in Renaissance France: Francus, Samothes, and the Druids (Edinburgh: Edinburgh University Press, 1993), p. 9-19.

${ }^{24}$ Jean Lemaire de Belges, Illustrations de Gaule et Singularitez de Troie, in Euvres, II, ed. J.-A. Stecher, (Louvain: J. Lefever, 1882), Book III, p. 267-272 and p. 272-4 and p. 274-6: 'De Laodamas, filz naturel d'Hector, lequel comme il est 
story diverging from the standard account of Astyanax's death, according to which he is thrown over the walls of Troy from a tower by the Greeks. The texts that allude to the young prince's survival are not very detailed but the tradition of 'Astyanax redivivus' has its own history, which begins with Strabo's Geographica and Servius' commentary of the Aeneid. In both cases, the young Trojan prince appears in relation to a city, ${ }^{25}$ and the reason behind his survival is not featured. Matteo Mario Boiardo's Orlando Innamorato (1495) and Ludovico Ariosto's Orlando furioso (1516-1532) propose more elaborate narratives. In both epic poems, Hector's son is not killed during the fall of Troy but saved by his mother, who carries in her arms another child as a substitute for her son, and hides the true heir from the Greeks. ${ }^{26}$ Ronsard's invention of the decoy of clouds, which draws on Italian epic poems and the Aeneid, has the advantage of bridging two foreign sources of inspiration to create a French epic and to anchor his modern epic as a new masterpiece gesturing towards an open future.

To understand the disbelief and uneasiness expressed by many early modern readers of the Franciade, it is necessary to go back to 'Ode de la Paix au roi' published

vraysemblable eut deux noms : car il fut aussi appelé Francus'. Laodamas was himself a character who featured in a book of the $12^{\text {th }}$ century, the account of the Trojan war by Dares and Dictys. See Beaune, Naissance de La Nation France, p. 21 and Asher, National Myths in Renaissance France, p. 15.

${ }^{25}$ According to Demetrios of Skepsis quoted by Strabo, Skamandrios and Ascanius stayed in Troad and displaced the inhabitants of Skepsis to another place (Strabo XIII, 1, 52). Servius, who, in another comment reports the details of Astyanax' death, also mentions the tradition of the survival of Astyanax (Commentary on Aeneid, IX, 261-262), in a remark about two silver cups (pocula).

${ }^{26}$ See Matteo Maria Boiardo, Orlando Innamorato, ed. Luigi Garbato, (Milan: Marzorati-editore, 1970), IV, p. 236-7, Canto III, 5, 18-21 and Ludovico Ariosto, Orlando Furioso, trans. Guido Waldman, (Oxford; New York: Oxford University Press, 2008), XXXVI, 70, p. 439. 
in 1550 and pay attention to the mode of appearance of Francion in Ronsard's poetic works. The problem of the epic lies not only in the choice to identify Francion with Astyanax but in the elaboration and assertion of this identification process - which because of the delays to the epic project's development — takes an unexpected turn.

\section{Francion in 'Ode de la Paix au roi'(1550)}

Ronsard wanted to write an epic but he wanted to do it in his own terms, at the behest of a royal command and with proper remuneration. This constraint is certainly the root of the delay and the unfinished state of the Franciade. ${ }^{27}$ While Ronsard is waiting for royal patronage, his strategy in his poetic works from 1550 to 1572 is to simultaneously reveal and conceal Francion, hoping that the constant advertising of the pending project, in its promising yet incomplete state, will lead Henri II, and then Charles IX, to take interest in the epic. The mode of appearance of Francion can therefore be described as ghostly, characterized by a form of uncertainty which blurs the lines between myths, dead and alive heroes, and which pretends to question the possibility of the epic itself.

Francion is first featured in the 'Ode de la Paix au roi' (also known as 'Ode de la Paix') which is published separately in 1550 , very shortly after the publication of Les Quatres Premiers livres des Odes. Ronsard uses the necessary celebration of the peace treaty of Outreau between France and England (1549) to defend his project of a modern epic for France by proposing a sample of the adventures of Francion. In the opening passage of this Trojan narrative, the prophetess Cassandra makes a prediction to Francion, who is presented as the son of Hector but whose identity is otherwise left unexplained. She tells the young prince that he will become the founder of a new dynasty of kings and

${ }^{27}$ See Bjaï, La Franciade sur le métier, chapter I, 'La Franciade pour Charles IX', p. 19-54. He explains the material difficulties that Ronsard encountered in the writing of the epic. 
urges him to leave Troy. The following scene takes place in Buthrotum in Epirus, where Francion, after a long sea journey, is unexpectedly reunited with his mother Andromache:

Il vit Andromaque pleurante Trois fois en pas tristes errante Cernant le vain tumbeau d'Hector:

Par sacrifice elle appelloit L'idole de l'ame Hectorée, Repandant du laict qui couloit Du fond de sa couppe dorée Mais quand son fils elle entrevit, Une pamoizon lui ravit La voix \& la bègue parolle Ayant de pleurs la face molle : A la fin serenant ses yeux Pandue à son col, ell' s'efforce De l'arrester par doulce force Violentant le vueil des Cieux.

$$
\text { Epode }
$$

Lors la tumbe en deus s'ouvrit, Et l'obscur de ses crevaces Hors des enfers se decouvrit Une ombre de quinze brasses. ${ }^{28}$

The end of this passage is featured the apparition of a ghost in the shape of Hector, yet the disruption within the poem is created by the character of Francion, whose identity is undermined by the intertextual echoes present in the text. He is the hidden ghost in the scene: it is his presence which disrupts the continuity of the narrative laid out for the readers.

This scene is a fine example of Ronsard's practice of necromantic imitatio, which could be defined as a syncretic yet hierarchized process of poetic imitation in which the main source is exhibited and transformed, bringing into being a new overarching French poem. ${ }^{29}$ The intertextual density of this scene, drawing on the Aeneid and the medieval

${ }^{28}$ Pierre de Ronsard, CEuvres complètes, ed. Paul Laumonier, (Paris: Librairie Droz, 1937), III, p. 15-6, v. 172-190.

29 I rely again on Thomas Greene's analysis of Ronsard's approach to what he calls 'imitative discovery' in The Light in Troy but also on Terence Cave's study on the 
tradition of Francion explored above, is hierarchized since one singular source among all the subtexts can be read as the model of the poem. In 'Ode de la paix' (1550), Ronsard wishing to praise his own project of epic, naturally turns to Virgil to find his inspiration and more specifically to the third book of the Aeneid. The matrix for this passage is the scene of reencounter between Aeneas and Andromache in Buthrotum, when Hector's widow mistakes Aeneas for a ghost when she first sees him:

sollemnis cum forte dapes et tristia dona libabat cineri Andromache, Manisque uocabat Hectoreum ad tumulum, uiridi quem caespite inanem Vt me conspexit uenientem et Troia circum arma amens uidit, magnis exterrita monstris deriguit uisu in medio, calor ossa reliquit ; labitur, et longo uix tandem tempore fatur : 'Verane te facies, uerus mihi nuntius adfers, nate dea ? Viuisne, aut, si lux alma recessit, Hector ubi est ? (...) ${ }^{30}$

She was pouring a libation to the ashes of her husband Hector, calling on his shade to come to the empty tomb, a mound of green grass on which she had consecrated two altars. There she used to go and weep. When she saw me approaching with armed Trojans all about me, she was beside herself, numb with fear, the moment she saw this great miracle, and the warmth of life went out of her bones. She fainted, and only after a long time was she at last able to speak to me: 'Is this a true vision? Is it a true messenger that comes to me, son of the goddess? Are you alive? If the light of life has left you, why are you here? Where is Hector?'31

It is beyond doubt that the encounter between Aeneas and Andromache in Buthrotum is the principal source of the poem: the settings and the narrative structures of both texts, except for the apparition of Hector's shade, are completely identical. Ronsard also imitates the Virgilian description of the funerary ritual in front of Hector's cenotaph and

links between copia and imitation: Terence Cave, The Cornucopian Text:

Problems of Writing in the French Renaissance, Reprinted (Oxford: Clarendon

Press, 2000).

${ }^{30}$ Virgil, Aeneid, III, v. 302-312.

31 Virgil and David West, The Aeneid, Rev. ed, Penguin Classics (London ; New York: Penguin Books, 2003), p. 57. 
he keeps the representation of Andromache's intense surprise and emotions when she first sees Aeneas in the Aeneid, changing only the identity of the character who provokes such a strong physical reaction. But this change is the crux of the poem, and points to several unresolved poetic and historical questions.

The problem of the 'Ode de la paix' lies in its direct confrontation between the Aeneid (specifically the encounter between Aeneas and Andromache), the intricate myth of Francion and the minor traditions of Astyanax's survival. This Ode brings to the forefront a Virgilian subtext which actively disassociates itself from the epic poem to come, obstructing the 'rite of passage' which is supposed to occur in heuristic imitation, ${ }^{32}$ and revealing the dynamic resistance of a subtext at the core of the imitation process.

In the Virgilian epic, not only is Astyanax dead, but his death is a critical element in the transfer (translatio) of the symbolic survival of Troy from Hector's direct relatives (Helenus and Andromache) to Aeneas' bloodline. Indeed, when Aeneas' fleet is about to leave Buthrotum, Andromache compares Ascanius to her deceased son Astyanax, effectively passing on the scepter of Troy to Aeneas' descendant, who is the living image of the lost heir. ${ }^{33}$ Therefore, the third book of the Aeneid, chosen by Ronsard as the frame of reference for the rise of Francion, is the passage in which the memory of the destruction of Troy and all its inhabitants, along with the decisive death of Astyanax, is the most prominent. It is also the reason for Andromache's initial confusion when she first glances

\footnotetext{
${ }^{32}$ Greene, The Light in Troy, p. 41.

${ }^{33}$ Virgil, The Aeneid, ed. D. West, p. 62: 'You are the only image left to me of my own son Astyanax. His face was just like yours. He would have been growing up now, the same age as yourself.'. In Latin: 'O mihi sola mei super Astyanactis imago./sic oculos, sic ille manus, sic ora ferebat;/et nunc aequali tecum pubesceret aevo.'
}

(Aeneid, III, v. 489-91) 
at Aeneas. It could be argued that the eerie atmosphere of the original scene contaminated Ronsard's poem by association. Indeed in this setting, the memory of the question asked by Virgil's Andromache to Aeneas 'vivisne?'('Are you alive?') is hanging in the air and seems even more relevant when it comes to seeing a new Astyanax risen from the dead, next to Hector's cenotaph. The verb 'entrevoir' (v. 179) - conveying the nuance of a blurred or imperfect vision - and the initial reaction which echoes Andromache's terror in the Aeneid, add more layers of mystery to the encounter between mother and son in Ronsard's poem.

In 1550, the dialogue between Virgil and Ronsard in this poem introduces a tension that gives an interesting density to the scene between Francion and Andromache through the complexity of its intertextual echoes. But because of the doubt cast on Francion's reality within the yet-to-come narrative, the 'Ode de la Paix' exhibits the fragility of the epic fiction and challenges the readers' capacity to believe in the whole project. This complex imitation also needs to be framed as part of Ronsard's meta-epic poetics and rhetorical strategy; one aimed at both the readership and the king of France.

In order to attract the king's attention - but also to kindle a more general desire for his epic - Ronsard highlights the uncertainty of the project and stresses how much the unfolding of Francion's adventures relies entirely on the king's patronage. Reassessing uncertainty as a core component of the early rhetoric concerning the Franciade allows us to rethink the conative function of Francion's ghostly aura and its unexpected consequences. The unanswered questions introduced by the elliptic 'Ode de la Paix' (Is Andromache seeing what she is seeing? Is Francion Laodamas or Astyanax? Is he a new Aeneas? ${ }^{34}$ How did he survive?) challenge the conditions in which the rise of the epic is

\footnotetext{
${ }^{34}$ Because Ronsard does not mention Francion's age nor the length of his sea journey, the temporality of the Trojan war is distorted. Francion behaves like a fully adult
} 
possible. The suspense this creates, however, also arouses the reader's curiosity. In Odes of 1555 , the dedicatory poem to Henri II was emblematic of Ronsard's strategy to encourage the king to intervene. Displaying images of incompleteness (in space and time), Ronsard suggests the possibility of an easy resolution of the tensions created by the delay of the epic:

Puis qu'il a donc trouvé le vent si à propos, Ne le laisse languir en casanier repos Aus rivages de Troie, ou sur les bors d'Epire, Fraudé de son chemin par faute de navire Et par faute de gens, car ouvrier je suis prest, De charpenter sa nef, \& dresser tout l'aprest, Pourveu que l'on me baille estoffes pour le faire Et qu'en le faisant bien je te puisse complaire. ${ }^{35}$

The epic hero is the prisoner of a temporal and spatial limbo because of the lack of royal support. And he is represented as always on the verge of starting his journey because the wind is propitious, and the poet is ready. The temporal threshold that Ronsard creates for his hero in the hope of obtaining a rewarding collaboration with the king also relies on Francion's uncertain identity, increasingly interpreted by early modern readers as a problematic ghostliness. The following section will explore how this game of literary pretense played by Ronsard was absorbed by the readers over time.

\section{Joachim Du Bellay and Jean de La Gessée}

The rhetorics of delay used in Ronsard's discussions of his epic reappears in poems by Joachim Du Bellay and Jean de La Gessée. Both poets engage with the latent content of

hero capable of leaving Troy on his own and therefore seems to belong to the generation of Aeneas and Andromache, who is supposed to be his mother. This problem will be resolved in the subsequent versions of 'Ode de la Paix'.

${ }^{35}$ Pierre de Ronsard, Euvres complètes, ed. Paul Laumonier (Paris: Librairie Droz, 1934), VII, p. 10, v. 93-100. 
the 'Ode de la Paix' by unearthing the presence of another Francion, never explicitly named, but clearly referred to as the Trojan prince who never left Troy.

Joachim Du Bellay is the first poet to voice a doubt regarding the epic, in his famous sonnet 23 of the Regrets (1558), emblematic of the ambivalent relationship between the two poets. ${ }^{36}$ Its critical and ironic tone targeted Ronsard's project and the delayed writing of the epic was again appropriately figured by the delay of Francion's epic journey:

Ton Francus, ce pendant, a beau haulser les voiles, Dresser le gouvernail, espier les estoiles, Pour aller ou il deust estre ancré desormais :

Il a le vent à gré, il est en equippage, Il est encor pourtant sur le Troyen rivage, Aussi croy-je (Ronsard) qu'il n'en partit jamais. ${ }^{37}$

This sonnet, inspired by Ronsard's rhetoric, raises questions about the true target of Du Bellay's satire. ${ }^{38}$ Was he implicitly blaming the king's delay to answer Ronsard's pleas for patronage by taking up Ronsardian expressions, or was he mocking Ronsard himself in a form of parody? The beauty of the poem resides not only in its pervasive ambiguity, but also in its manipulation of tenses. Du Bellay first represents Francion in present tense, about to depart from the Trojan shore and he then emphasizes the delay via the conditional use of the passé simple of the verb 'devoir' ('où il deust estre ancré desormais'). He plays with tenses by contrasting a scene in present - the expressions of delay and impatient projections onto a constantly deferred departure heightening a sense of temporal distortion - with the 'pointe' of the sonnet breaking into preterite ('il n'en partit jamais').

\footnotetext{
${ }^{36}$ See Monferran

${ }^{37}$ Joachim Du Bellay, Les Regrets: suivi de Les antiquités de Rome, Le songe, ed. François Roudaut, (Paris: Libr. Générale Française, 2002), sonnet 23, p. 68, v. 9-
} 14. 
The 'Troyen rivage' has a double-edged function since it refers to both the point of departure of Francion's future journey, and to the place that sealed Astyanax's fate in the distant past. Through this dense expression 'il n'en partit jamais', the ghost of Astyanax implicitly emerges. Although we could argue for a form of continuity between Ronsard and Du Bellay (insofar as the presence of Astyanax is prepared by Ronsard's choice of sources in 'Ode de la paix') we notice a structural shift. Du Bellay places the emphasis on the deceased child and not on Francion by choosing to end the sonnet on this evocative temporal rupture.

In the 'Remonstrance à Pierre de Ronsard', published after the Grasinde (1578), La Gessée is much more explicit in his reference to the other possible fate of Francion:

Ton hardi Francion, sauvé du sac Trö̈en, Aura le ciel propice, aura le vent en poupe Pour meshui s'embarquer avec toute sa troupe, Courant méme fortune : \& malgré les dangers En armes deffier les Princes estrangers, Franchir le Rhin Germain, \& par fatalle guerre Se faire enfin seigneur de la Gauloise terre : Où deja si long temps nous l'avons attendu, Que nous craignons (Ronsard) qu'il soit mort, ou perdu : Ou qu'aveques sa Ville aus Grecs il fut en proye, Et qu'il ne partit onc des rivages de Troye. ${ }^{39}$

Taking his cue from Du Bellay, La Gessée also complains about the Franciade's delay by means of the metaphor of Francion's absence. He also shifts between present tense ('nous craignons (Ronsard) qu'il soit mort ou perdu') and preterite ('il fut en proye', 'il ne partit onc'). The classical account of Astyanax's murder appears more explicitly as La

39 Jean de La Gessée, 'Remonstrance à Pierre de Ronsard', La Grasinde, (Paris: Galliot Corrozet, 1578), ff 26-30, v. 28-39. More details can be found about the context of the publication of this text and the erroneous protestant flavour that was attributed to this exhortation in Bjai, La Franciade Sur Le Métier, p. 408-18. 
Gessée's reference to death ('qu'il soit mort') and his allusion to the fall of Troy ('Ou qu'aveques sa Ville aus Grecs il fut en proye') expand upon the condensed expression of Du Bellay's sonnet. The gradation between one isolated expression of disbelief in Les Regrets ('aussi croy-je') to a more general concern shared by a 'nous' ('nous craignons') in the 'Remonstrance', draws our attention to the shared representation of the epic endeavour as increasingly under threat from the invasion of a rival tradition.

Following the reception of Francion's character we notice that the rhetoric used by Ronsard was taken up by his readers but also transformed because of the emphasis put on Astyanax's myth. It is unclear how seriously we need to take the criticisms of Du Bellay and La Gessée, who as both admirers/imitators and rivals of Ronsard, use irony to create distance and promote the singularity of their own work (Les Regrets and the Grasinde) in thematic oppositions similar to Schélandre's rhetoric to promote the difference of the Stuartide ${ }^{40}$ Yet, we notice a shift in the rhetoric about the claimed limits of the epic, staged by Ronsard as a possibility but programmed to be easily resolved by the king's patronage, as it gradually enter the linguistic field of belief, more specifically disbelief and fear, responses which characterized encounters with ghosts in early modern France. ${ }^{41}$ It is in light of these expressions of disbelief that I now turn to examine the corrections made by Ronsard to 'Ode de la Paix', which can be read as a response to the problem of Astyanax's ghostly presence.

40 On Du Bellay's display of aesthetic oppositions between himself and Ronsard, see in particular Jean-Charles Monferran, « La Deffence et Illustration de la langue françoyse : un œuvre ronsardien ?», Littérales, 26, 2000, p. 101-118.

${ }^{41}$ See for example the definition by Le Loyer: 'Spectre est une apparition d'une substance sans corps qui se montre sensiblement aux hommes contre l'ordre de nature et leur donne frayeur' and the interpretation by Chesters, Ghost Stories in Renaissance France, p. 145. 


\section{Corrections of 'Ode de la Paix' (1560-1578)}

The many corrections made to Francion's myth in the versions of 'Ode de la Paix' and in the Franciade can be interpreted as efforts to resolve the literary disruption introduced by the ghost of the dead Astyanax. Ronsard invented a new myth for Francion, one which was intended to conjure the memory of Astyanax and to appease his readership. ${ }^{42}$ Like Ronsard's inclusion of Francion's ghostly presence in 1550, this story also had a metapoetic function aiming to create a clear distinction between the classical account of Astyanax's death and the reality of Francion's survival within the new narrative.

The first corrections made by Ronsard had the effect of gradually erasing the memory of the Virgilian scene of reencounter with Andromache. Firstly, in the 1560 'Ode de la Paix', the character of Andromache was presented as dead and the whole scene between mother and son was therefore erased, with the exception of the passage involving the apparition of Hector's shade next to the cenotaph. ${ }^{43}$ Secondly, in the 1578 version of the same ode, the passage was completely transformed: Francion's arrival in Buthrotum was only followed by a scene of funerary rituals next to Hector's empty tomb. Andromache's death, was likewise rapidly related, and Hector's shade completely

${ }^{42}$ This expanded version of this tale appears in the Franciade (1572), and is presented in a long speech by Jupiter who narrates to Juno how he saved Francion: 'Lors en sa place une feinte je fis, /Que je formay du vain corps d'une nue,/Pour estre un jour en lieu de luy cognue/Du tout semblable à l'heritier d'Hector,/ [...]/Puis ceste feinte à la mère je baille/ Pour la donner à Pyrrhe, et tout soudain, /Enveloppant l'enfant dedans mon sein, /Loing le sauvay de l'espée homicide. /Le vain sans plus fut proye d'Æacide!', Ronsard, Euvres complètes , ed. Laumonier, XVI (1), p. 356, v. 108-18.

${ }^{43}$ Pierre de Ronsard, Euvres Complètes, ed. Prosper Blanchemain, (Paris: P. Jannet, 1857), II, p. 29-30, v. 157-86. 
removed. ${ }^{44}$ We can conclude from these changes in the last version of the Ode, that the classical source was still present. Yet, by means of a series of displacements, the specific passage of the Aeneid - with its problematic reminiscences - completely disappears. ${ }^{45}$

The second major addition, that also participated in dismissing the deceased Astyanax, was based on decoy of clouds. This was critical in order for the readers to believe in a poetic fiction based on the survival of Francion. Focusing on the vocabulary used to describe the decoy in the two later versions of the 'Ode de la paix', I propose an explanation for the change between the expression 'une idole à lui ressemblante' (Ode 1560, v. 166) and 'a semblance animée' (Ode 1578, v. 166). It was in the 1560 'Ode de la paix', ten years after the first version, that Ronsard first tried to reconcile the story of Francion with the classical version of the ransacking of Troy and explained how the young child survived because Venus created a decoy made of clouds named 'idole':

Andromache qui remâcha Les mots de Cassandre esvolee Son fils secrettement cacha Dessous figure recelee. Car Junon qui ne vouloit plus Que le nom Troyen revint sus, Ardoit d'en abattre la race, Et Francus tuer sur la place, Sans Venus qui soudain faignit Une idole à lui ressemblante Dont Junon d'une main ardente En lieu de Francion taignit Antistrophe

La terre de sang \& la feinte

${ }^{44}$ Pierre de Ronsard, Euvres complètes, nouv. ed. Jean Céard, Daniel Ménager, Michel Simonin, Bibliothèque de la Pléiade 45 (Paris: Gallimard, 2009), I, p. 597-8, v.157-86.

${ }^{45}$ In the Franciade, in which Andromache's character is alive, some elements of this constitutive scene are also transposed: for example, the shade of Hector appears not to Francion but to Helenus. See Ronsard, Euvres Complètes, ed. Laumonier, XVI (1), p. 61-3, v. 631-76. 
Garda le vrai, $[\ldots]^{46}$

The word 'idole' comes from the Greek eidolon ( $\varepsilon i \delta \omega \lambda \circ v)$ and can refer in Ronsard's poems to many different realities: an idol, a phantasy, a ghost or an image. In the 1550 'Ode de la paix' we find for example the expression 'idole de l'âme Hectorée' ${ }^{47}$ which refers to the Manes of Hector. In the version of 1560, the 'idole' created by Venus to delude Pyrrhus takes the form of a double, an image and an illusion. In the Iliad, the gods often use eidola ( $\varepsilon i \delta \omega \lambda \alpha)$ as decoys during battles to protect epic heroes from danger. ${ }^{48}$ The 'idole à lui ressemblante' belongs to this category of ghostly decoys. This precise 'idole' draws on the 'umbra' of Aeneas created by Juno in the tenth book of the Aeneid. Ronsard translated the expression 'umbram in faciem' by 'idole à lui ressemblante':

tum dea nube cava tenuem sine viribus umbram in faciem Aeneae (visu mirabile monstrum) Dardaniis ornat telis, clipeumque iubasque divini adsimulat capitis, dat inania verba, dat sine mente sonum gressusque effingit euntis, morte obita qualis fama est volitare figuras aut quae sopitos deludunt somnia sensus. ${ }^{49}$

Then she fashioned out of empty vapour an effigy in the form of Aeneas, a weird sight, a shade without strength or substance, armed with Trojan weapons. She copied the shield and the crest on his godlike head and gave the phantom power to speak in empty words. Sound without thought she gave it, and moulded its strides as it moved. It was like the flitting shapes which men say are the ghosts of the dead, or like the dreams which delude our sleeping senses. ${ }^{50}$

\footnotetext{
${ }^{46}$ Ronsard, Euvres Complètes, ed. Prosper Blanchemain, I, p. 29-30, v.157-70.

${ }^{47}$ Ronsard, CEuvres Complètes, ed. Laumonier, III, p.15, v.176

${ }^{48}$ See for example: Homer, Iliad, III, v. 381 (Aphrodite rescues Paris), Iliad, V, v. 44950 (Apollo creates a false Aeneas to fight Diomedes).

${ }^{49}$ Virgil, Aeneid, X, v. 636-42.

${ }^{50}$ Virgil, The Aeneid, translation D. West, p. 229. This phantom is inspired by the decoy of Aeneas created by Apollo in Iliad V, see above, note 35.
} 
Although Ronsard uses the word 'idole' regularly to refer to ghosts and apparitions, this word has been worked in the context of amourous poetry. In the Amours of 1552, the Petrarchan 'idolo' is reworked into a Greek 'idole' which is an image that 'affole' the poet. $^{51}$ The word 'idole' in Ronsard's poetry therefore is often associated with a dangerous powers of a moving image which is alive. To go back to Francion's decoy, although Ronsard opts for the word 'feinte' in the Franciade, he changes the expression to 'semblance animée' in the 1578 version of 'Ode de la Paix', by means of a functional shift, transposing the nominal form 'semblance' into the adjective 'ressemblante':

Andromache qui remâcha Les mots de Cassandre esvolee Son fils secrettement cacha Sous une voute reculee. Car Junon qui ne vouloit plus Que le nom Troyen revint sus, Ardoit d'en abattre la race, Et Francus tuer sur la place, Sans Jupin qui l'enfant mua En une semblance animee, Que Pyrrhe de sa main armee, D'une tour à terre rua.

\section{Antistrophe}

De faux sang la place fut teinte :

Ainsi la fraude de la feinte

Le corps de Francion sauva. ${ }^{52}$

To explain this shift, I argue that Ronsard emphasizes the distinction between the real Francion and his double by depriving the decoy of all agency. An 'idole' is a problematic simulacrum. Its capacity to move gives it ghost-like agency and this appearance of life, useful for luring the enemies, also creates doubt. ${ }^{53}$ On the contrary, describing it as a

51

${ }^{52}$ Ronsard, Euvres complètes, ed. Jean Céard, I, p. 597-8, v. 157-71.

${ }^{53}$ See Terence Cave on how the recognizing life comes through the cognitive recognition of movement which is associated with agency in movement is triggers an association with life and agency. Terence Cave, Thinking with Literature: 
'semblance animée' (animated likeness), reifies (or objectifies) the 'idole' and transforms it into a passive object without agency. It remains a harmless illusion, an inanimate likeness, 'animée' only by the control of the gods. Similarly, in the Franciade, Ronsard insisted that the material used by Jupiter to create the decoy was 'le vain corps une nue', as if to emphasize the lack of humanity of this simulacrum, echoing the material used by Juno in Aeneid X, 636 ('nube cava', 'empty vapour').

Ronsard attempts to draw a line between reality and fiction by introducing a decoy, inspired by Orlando Innamorato and Orlando Furioso, but also by Aeneas' ghostly decoy in Aeneid X. The problematic agency of the 'idole' is progressively deconstructed and named 'feinte' in 1572, but it remains problematic. If we understand 'fantosme' as a reference to this 'idole' made from 'le vain corps d'une nue', then Schélandre's expression 'la vanité d'un fantosme' with the emphasis on 'vanité' is telling. Schélandre characterizes the decoy as a 'fantosme'- rejecting Ronsard's coinages - but also objects to its supposedly pivotal role in founding 'la majesté de cent rois' in the epic narrative.

\section{François de Belleforest and Jean Le Bon}

To further our understanding of the reception of Francion's character, I will analyse the word choices of two authors who explicitly referred to the problematic identity of the epic prince of the Franciade: François de Belleforest and Jean Le Bon. For Belleforest, writing from a historical perspective, Ronsard's choice to claim that Astyanax could be alive, and his inclusion of the decoy, are so unlikely and bizarre that they are proof enough that the origins of the French can not be found in Troy. I focus my analysis on several variations

Towards a Cognitive Criticism, First edition (Oxford: Oxford University Press, 2016) p. 8-10. 
of the same idea extracted from Belleforest's works: Les chroniques et annales de France,$^{54}$ La Cosmographie universelle ${ }^{55}$ and Les grandes annales et histoire générale de France.${ }^{56}$ Le Bon is the author of a short book entitled De l'origine et invention de la rhyme, ${ }^{57}$ written in 1574 but published in 1582, which is preceded by an Advertissement dedicated to Ronsard. ${ }^{58}$ In this prefatory text, preceding an essay focused on questions of verse, Le Bon expresses his great dissatisfaction with the 'Catalogue des rois' of the Franciade as well as with the story of Francion-Astyanax.

Belleforest and Le Bon are caught between their admiration for Ronsard's inventive Trojan myth, and their veneration for the story of Astyanax's murder. The religious vocabulary ${ }^{59}$ present in their writings reflects a shared notion of this classical subtext as already alive and resistant to another resurrection precisely because it is not dead. Astyanax's story - as part of the Trojan myth revitalised by Renaissance - already has a life its own in the mind of the readers. Ronsard's individual 'revivalist initiative'

${ }^{54}$ François de Belleforest, Les chroniques et annales de France [...], (Paris: Gabriel Buon, 1573).

${ }^{55}$ François de Belleforest and Sebastian Münster, Cosmographie universelle, (Paris: Michel Sonnius, 1575).

${ }^{56}$ François de Belleforest, Les Grandes annales et histoire generale de France [...], (Paris: Gabriel Buon, 1579).

${ }^{57}$ Jean Le Bon, De l'origine et invention de la rhyme, A Ronsard, (Lyon: Benoît Rigaud, 1582).

${ }^{58}$ It is a continuation of a 1568 Advertissement dedicated to Ronsard and advocating against the German ascendance of the French. Jean Le Bon, Advertissement [...] à Ronsard. Touchant sa Franciade, (Lyon: Benoît Rigaud, 1568).

${ }^{59}$ The religious aspect of 'reproductive imitation' is explored by Greene in his paragraphs about the sacramental strategy of imitation (The Light in Troy, p. 38-9). 
clashes with a living myth which is designated by Belleforest as an 'article de foy Poëtique':

nostre grand Poëte Gaulois, Pierre de Ronsard, [...] ne sçachant, dis-je où prendre ce Francus donnant source à nos François, à cause que tous dient, et le tiennent pour un article de foy Poëtique, que cest Astianax fut precitpité du hault d'une tour, $\left[\ldots . .{ }^{60}\right.$

Le Bon also attacks the unconvincing equivalence between Francion and Astyanax as 'peu croyable':

Ce propos me faict entrer en ta Franciade, pour t'advertir que tout ton argument n'a contenté personne pour l'histoire estre trop inveterée, \& receu du petit Astianax, que pour la ramener en fable si peu croyable, \& est vraysemblable à tous hommes qui ont du sang aux ongles $[\ldots]{ }^{61}$

The persisting presence of Astyanax in Ronsard's epic makes early modern readers like Belleforest and Le Bon rethink the function of classical sources as more than mere models or materials for their own creations. It challenges the standard meaning of necromantic imitation, by revealing that some stories' vitality precedes the attempt to revitalize them. Although Ronsard attempts to answer his critics by making reference to the Aristotelian dichotomy between history and fiction in the 'Epistre au Lecteur', the debate demonstrates that the problem of literary faith - or what Belleforest calls 'la foy poëtique', Le Bon 'vraisemblable', and which seems to be included in Ronsard's Aristetolian definition of "vraysemblance' ${ }^{62}$-cannot be easily resolved. These

${ }^{60}$ Belleforest, Les Grandes annales et histoire generale de France, 'Diverses considerations sur l'origine des Francoys', A2r sig.

${ }^{61}$ Le Bon, De l'origine et invention de la rhyme, A Ronsard, p. 20.

62 'L'Histoire reçoit seulement la chose comme elle est, ou fut sans deguisure ny fard, \& le Poëte s'arreste au vraysemblable, à ce qui peut estre, \& à ce qui est desja receu en la commune opinion', Ronsard, Euvres complètes, ed. Laumonier, XVI (1), p. 4. 
expressions are attempts to pin down the persistence of a single story, one which is not only asserted by a set of revitalized texts, but also by the living memory of readers who select and poetically believe in some images or stories rather than others.

This selective process is evident in the choice of names used to refer to the Trojan prince by Belleforest, Le Bon and Schélandre. It is noteworthy that Schélandre and Le Bon both only refer to Astyanax without naming Francion. Belleforest holds an intermediary position and stresses the uncertainty of Francion's identity by accumulating his various names. He calls him for instance: 'ce Francus chef du nom François, qui aussi s'appeloit Astianax, [...] $]^{63}$ and in Cosmographie Universelle, he uses three names ('Laodamas, ou Astyanax, ou Francus') as if they were equivalent:

D'autres des Troiens suivirent cest ombrageux Laodamas, ou Astyanax, ou Francus, que le seigneur de Ronsard en sa Franciade tire des nues, ne l'ayan ny sceu trouver en terre, que mort par la cruauté Grecque, qui ne vouloit laisser aucune memoire de ce puissant Prince Hector, duquel Astyanax estoit le fils unique. Ce Francus, ou Astyanax, est celuy qu'on nous fait père des Françoys, et lequel on songe avoir peuplé les Gaules du nom Françoys, et donné origine à la nation Françoise. ${ }^{64}$ (my emphasis)

Naming Francion, the eponymous hero of an epic whose name contains the symbolic etymology and vital origin of the French nation, is no small matter. ${ }^{65}$ This quotation

${ }^{63}$ Belleforest, Les chroniques et annales de France, 'De l'origine des François et de leur venue en Gaule', A1v sig.

${ }^{64}$ Belleforest and Münster, Cosmographie universelle, in 'Du Pays d'Anjou et singularitez d'iceluy, de l'antiquité et excellence de la ville d'Angers, Evesques \& Princes qui y ont commandé, \& des mœurs des Angevins' (second part), part II, col. 56 .

${ }^{65}$ On the belief and debate on a motivated etymology of the name 'Francus' and 'France' and its function as surname we refer to the article by Adeline Desbois-Ientile, 'L'interprétation des noms propres à la Renaissance : l'exemple de Francus', Le Français Préclassique 1500-1650, 2014, 16, p. 97-109. The etymology of the name Francion is explained in the Franciade, when the young prince changes his name 
represents the ambivalence of Francion's character as a founding father, via the impossibility of overcoming his double or three-folded name. ${ }^{66}$ Belleforest also coins a paradoxical expression to refer to Francion in Chroniques and Annales de France: 'Cest excellent homme cognoissant le peu de moyen que les fabuleux historiens ont de se couvrir à faire vivre ce Francus precipité, l'a sauvé avec ceste fiction nuageuse du precipice [...]'. ${ }^{67}$ The expression 'Francus précipité' is a pure antinomy from a Ronsardian perspective, since the whole point of the decoy is to assert that Fancion did not fall from the walls of Troy. It thereby illustrates the prevalence of Astyanax's myth, even when Francion's name is used.

\section{Conclusion}

By following Ronsard's creation of Francion - a genesis which paralleled the rise of the ghost of Astyanax in the readers' writings - it is possible to better understand the

from Astyanax to Francus: 'Adonq Francus qui seul prince commande,/Pront \& gaillard au millieu de la bande,/ Voulant sa main d'une lance charger,/D'Astyanax en Francus fit changer/ Son premier nom, en signe de vaillance/Et des soldats fut nommé Porte-lance,/Pheré-enchos, nom, des peuples vaincus/Mal prononcé, \& dit depuis Francus', Ronsard, Euvres Complètes, ed. Laumonier, XVI (1), p. 76-7, v. 945-52.

${ }^{66}$ Desbois-Ientile shows in her article that the origin of the word 'France' during the $16^{\text {th }}$ century is less and less attached to the character of Francion (like Pasquier who mocks the belief that it is possible to find, through the etymology a founding father) but is explained by a paronomy with 'ferox' or 'franc', Adeline Desbois-Ientile, 'L’interprétation des noms propres à la Renaissance : l'exemple de Francus', Le Français Préclassique 1500-1650, 2014, 16, p. 97-109.

${ }^{67}$ Belleforest, Les chroniques et annales de France, A1v sig. 
complex imitation of an eclectic range of sources that led to the problematic resurrection of Astyanax as a rival for the new epic hero. I argue that the equivalence between Francion and Astyanax (which, from a historical perspective, was problematic) pales in comparison with the mode of apparition of the epic hero. If, in 'Ode de la Paix', Ronsard surrounds his new character with an aura of mystery, the early modern readers immediately pick up on the implicit competition between Francion and his deceased double Astyanax. The subsequent modifications of the same 'Ode' alongside the final version of the myth in the Franciade, bear witness to Ronsard's attempts at resolving the tensions between his classical source and his new epic material. But the invention of the decoy of clouds intended to bridge the two stories and assert Francion's reality - proved to have a different effect on Renaissance readers, who remained obsessed with this sequence which kept gesturing towards the fate of Astyanax. 